\title{
Study of water management on rainfed land in downstream Renggung watershed
}

\author{
Fahrudin \\ Graduate student of Dryland Resources Management, University of Mataram, Jl. Majapahit No. 62 Mataram, Nusa \\ Tenggara Barat, 83125 Mataram, Indonesia, e-mail: fach0604@gmail.com
}

Muhamad Husni Idris

University of Mataram, Department of Dryland Resources Management, Mataram University, Jl. Majapahit No. 62 Mataram, Nusa Tenggara Barat, 83125 Mataram, Indonesia

\author{
Mahrup \\ University of Mataram, Agriculture Faculty, Mataram University, Jl. Majapahit No. 62 Mataram, Nusa Tenggara Barat, \\ 83125 Mataram, Indonesia
}

\begin{abstract}
The downstream area of Renggung Watershed is a water conservation zone which is also dominated by rainfed land with dominant vertisol soil-clay fraction. Watershed downstream reaches $40 \%$ and is $30 \%$ of total area of Renggung Watershed. Rainfed farming is a factor in dry land farming, but the presence of rainfed land in downstream Renggung watershed does not receive intensification treatment as water becomes a limiting factor for plant growth. About 87-90\% rainfall events in downstream Renggung watershed happen during the rainy season, from November to April, with 3-4 wet months, while about 10-13\% happen during the dry season, from May to October. This means that water is abundant in wet months, but there is a shortage of water during the dry period. Based on zone group, $72 \%$ of potential water from rainfall occurs in the downstream zone, $18.3 \%$ occurs in the middle zone, and $10.4 \%$ in the upstream zone. Three quarters of potential water from rainfall occurs in downstream. Water management on rainfed land in downstream Renggung watershed is still not optimum, which is caused by (a) dependence on supply of water downstream from HLD BR, but discharge has declines in the last six months; (b) poor water management at the farming level, because plants are not cultivated in the right season; and (c) poor management institutions and water user groups, so forums to facilitate and mediate issues in terms of management and use of irrigation water is not optimal.
\end{abstract}

Keywords: rainfed, Renggung watershed, water management

Submitted 31 May 2016, revised 20 September 2016, accepted 3 November 2016

\section{Introduction}

Some areas, like on rain-fed lands in the province of West-Nusa Tenggara (NTB), particularly at Lombok Island, still rely on rain water for agricultural purpose. The productivity of rainfed land depends on the existence of rainwater as an agricultural input. Rainfed land has the potential to replace irrigated-technical areas, which have been converting land use in the last few decades with the growth in population and economy. If water management for irrigation in this area is conducted optimally, this potential can be developed to support local and national food security.

Central Lombok is a regency which has the largest amount of rainfed land among other regencies/cities in Lombok Island. Central Lombok Regency has 13.642 ha rainfed area; West Lombok reaches 3.328 ha; East Lombok reaches 1.724 ha; and North Lombok reaches 211 ha (BPS
2014). About $80 \%$ of the agricultural areas in downstream of Renggung Watershed (DAS) use the crop rotation technique. It is planted with paddy fields in rainy season then rotated with palawija (soybeans and green beans) as a second crop in dry season. Soil in downstream Renggung watershed has a high content of clay (40-70\%) (Idris et al. 2014). This soil is vertisols, which have a decisive shrinkswell potential. It is relatively difficult to cultivate because it is highly plastic in wet conditions but very hard in dry conditions. Nevertheless, this soil is naturally suitable for farming because it can store water in large quantities for a long time, even in low annual rainfall (i.e. ranges up to $1200 \mathrm{~mm} /$ year.)

The cultivation of crops, palawija and some types of horticultural (tomatoes, peppers, watermelon, etc.) for the farming communities in central Lombok is a culture inseparable from agricultural activity. Lack of water availability is the main problem in some subdistricts in 
downstream Renggung watershed. It is caused by the fact that the main irrigation water supply is from rainfall which is relatively short and often erratic (erratic rainfall). It can cause a decrease in plant productivity and crop failure. In other words, the level of land productivity is controlled by the water supply from Renggung watershed, especially during dry season (Agus 2000; ACIAR 2007).

Based on previous research, several problems in the rainfed area of downstream Renggung watershed were identified, and one of them is the problem of water resources (Alfian 2012; Markum et al. 2014). The water management aspect has a significant role determining plant productivity, so the study of water management on the rainfed area in downstream of Renggung watershed is critical.

\section{Materials and Methods}

The method in this study was a descriptive study using a quantitative and qualitative approach (Nazir 2005). The quantitative descriptive research was to determine the needs of irrigation water on the rainfed area in downstream Renggung watershed. The qualitative description was to describe the implemented management in Renggung watershed.

The location of the research was in upstream (Aik Bual Village, Kopang Subdistrict), middle-stream (Selebung Village, Janapria Subdistrict), and downstream (Sukaraja Village, Praya Timur Subdistrict) Renggung watershed, administratively located in Central Lombok Regency (Fig. 1). Data (width, use, and productivity of land area) will be analysed descriptively to provide a description of the study of management on rainfed, moor, and semi-irrigated land in downstream Renggung watershed.

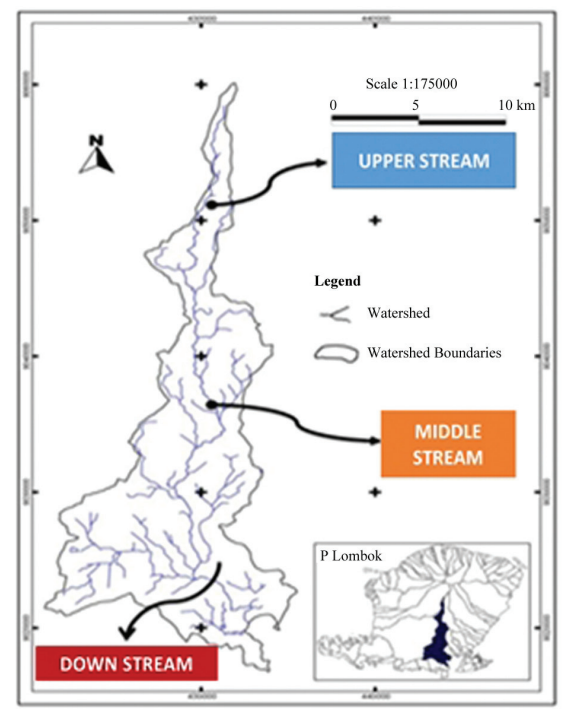

Fig. 1. Location of research observation in Renggung Watershed (FFI 2013)

\section{Results and Discussion}

\subsection{General description of Renggung watershed downstream}

The geographical position of Renggung watershed is $8^{\circ} 38^{\prime} 4^{\prime \prime} \mathrm{SL}$ and $116^{\circ} 21^{\prime} 31^{\prime \prime} \mathrm{EL}$ and about $93.8 \%$ is located in Central Lombok, while about $4.3 \%$ is in East Lombok. The width of Renggang watershed is about $215.99 \mathrm{~km}^{2}$. The downstream Renggung watershed area belongs to 29 villages in six subdistricts (Table 1).

Table 1. Total area in downstream Renggung Watershed; source: International of Fauna \& Flora 2012 (Data processed; area is village/subdistrict in Renggung Watershed)

\begin{tabular}{|l|c|r|r|}
\hline \multirow{2}{*}{$\begin{array}{c}\text { Administrative area } \\
\text { Regency/Subdistrict) }\end{array}$} & \multirow{2}{*}{ S Villages } & \multicolumn{2}{|c|}{ Area } \\
\cline { 3 - 4 } & & \multicolumn{1}{c|}{$\begin{array}{c}\text { hatershed } \\
\text { Area }\end{array}$} \\
\hline Central Lombok & 5 & 1567.11 & 10.5 \\
\hline - Central Praya Subdistrict & 9 & 5182.41 & 34.8 \\
\hline - East Praya Subdistrict & 11 & 7226.01 & 48.5 \\
\hline - Pujut Subdistrict & 25 & 13975.53 & 93.8 \\
\hline Total of Central Lombok & & & 0.3 \\
\hline East Lombok & 2 & 396.20 & 2.7 \\
\hline - Montong Gading Subdistrict & 1 & 48.97 & 3.2 \\
\hline - Terara Subdistrict & 1 & 478.60 & 6.2 \\
\hline - Jerowaru Subdistrict & 4 & 923.77 & 100 \\
\hline Total of East Lombok & 29 & 14889.30 & \\
\hline $\begin{array}{l}\text { Total of downstream } \\
\text { Renggung Watershed }\end{array}$ & & &
\end{tabular}

Table 1 shows that about $93.8 \%$ of the downstream area of Renggung watershed is located in Central Lombok Regency, while about $4.3 \%$ is in East Lombok Regency. Therefore, this study is focused in Central Lombok regency, especially in the Praya Timur, Central Praya and Pujut Sub District (Table 1). Upstream of Renggung Watershed is a water productive zone, but downstream is a water conservation zone. Downstream of Renggung watershed is a centre of rainfed agricultural and upland/moors. In this region, rainfall is relatively low, so there are many water reservoir buildings for water management in downstream Renggung watershed.

\subsection{Physical condition and climate of rainfed land in downstream of Renggung watershed}

\subsubsection{Physical condition of rainfed land}

The rainfed zone in downstream Renggung watershed is dominated by vertisol soil type (Fig. 2). The soil profile shows that vertisol soil type has high content of clay, so it is difficult in processing (Fig. 3). Physically, vertisol soil is dark gray coloured and clay textured (clay; heavy texture) 


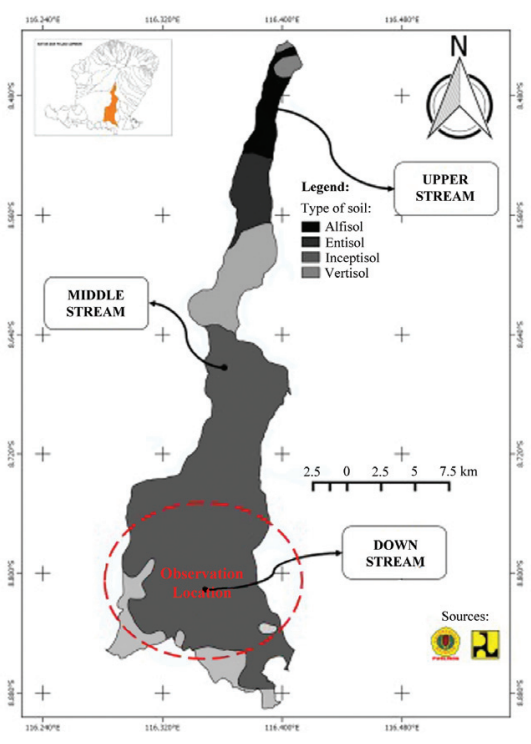

Fig. 2. Map of Renggung Water shed soil type (BISDA 2012)

with a relatively deep solum $(>1 \mathrm{~m})$. This soil is composed of montmorillonite clay mineral. This means that the shrink/swell potential of soil depends on the moisture condition. It is very sticky and slippery in wet conditions (rainy season), but it is very cracked in dry (dry season). The soil texture is classified as high clay with a level of clay fraction is greater than $50 \%$, so it has high ability to store water (water holding capacity) (Idris et al. 2014).

Vertisol soil has high $\mathrm{pH}$, cation exchange capacity $(C E C)$, and alkali saturation. Nevertheless, organic matter content of vertisol soil is generally low because of a lack of covering of organic materials. Soil fertility is classified with moderate to high content of potassium (K), but nitrogen $(\mathrm{N})$ and phosphorus $(\mathrm{P})$ content are generally low to moderate (Rachman et al. 1989; Haryati 1992, 1995; Ma'shum 2005).

Figure 4 shows that land use in Renggung watershed is largely dryland agriculture and paddy fields; about 30 $40 \%$ is located in the downstream of the watershed. Dryland farming consists of rainfed land, moors, and gardens. The presence of rainfed land in downstream Renggung Watershed barely get intensification treatment because agricultural management is only effective when there is

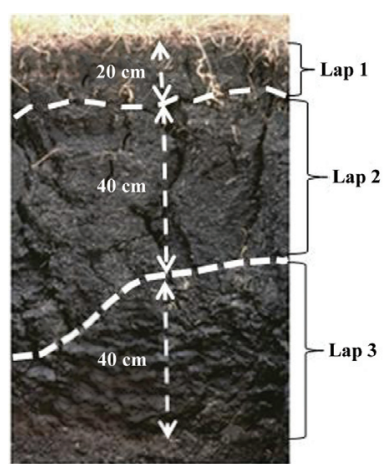

Fig. 3. Soil profile in downstream of Renggung Watershed

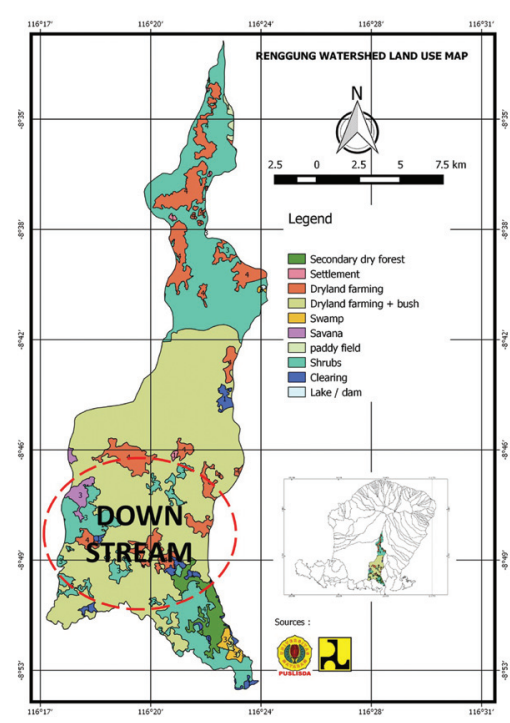

Fig. 4. Renggung watershed land use map

limited water available. Meanwhile, secondary dry forest and forest plantations upstream of the watershed only cover $1.7 \%$ of total watershed area (Idris et al. 2014).

\subsubsection{Climate conditions of rainfed land}

Based on Oldeman Climate Classification, downstream of Renggung watershed has D3 to D4 climate type (Fig. 5) with $4-6$ dry months (rainfall $<100 \mathrm{~mm}$ per month) and 3-4 wet months (Oldeman et al. 1980). Annual rainfall in rainfed area in downstream Renggung Watershed is about $1200 \mathrm{~mm} /$ year.

Water scarcity greatly inhibits the process of agricultural production, especially in dry land with dry climates. Rain is the main source of water for plants in most parts of Indonesia. Approximately 1\% of 183 million hectares of land in Indonesia has annual rainfall $>1.000 \mathrm{~mm}$. In arid and semi-arid areas, rainfall $>1.000 \mathrm{~mm}$ can support agriculture with the implementation of water-saving tech-

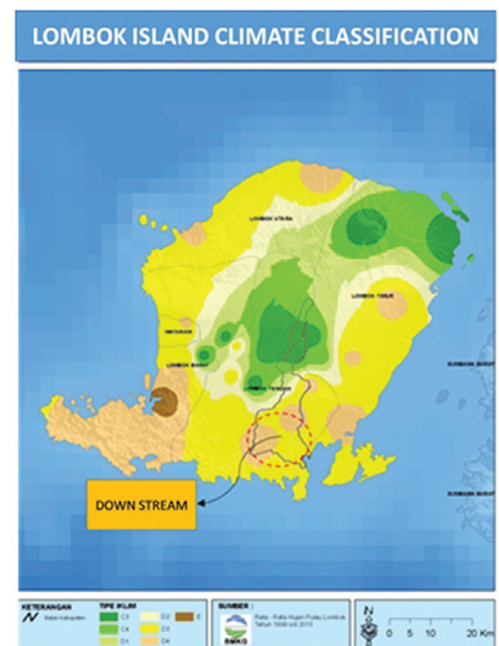

Fig. 5. Lombok Island climate classification (BMKG, NTB) 
nology (Latham 1987). Rainfall ofi $1.000 \mathrm{~mm} /$ year will be able to support the production process of seasonal crops for two seasons with the assumption that the water need for seasonal crops in dry land is $120 \mathrm{~mm} /$ month (Oldeman et al. 1980; Sutono et al. 1997).

About $87-90 \%$ and $10-13 \%$ potential water from precipitation in dry land areas occurs in the rainy season (November-April) and the dry season, respectively. This means that the availability of water is abundant in wet months, but it decreases in dry months. In the upstream zone, $78 \%$ and $22 \%$ rainfall occur in wet months and dry months, respectively. In the middle zone, about $84-87 \%$ and $13-16 \%$ rainfall occur in wet months and dry months, respectively.

\subsection{The condition of water resources in downstream Renggung watershed}

The south side of Rinjani Mountain is upstream of Renggung Watershed, and is a supplier of agricultural irrigation water in the downstream, wherein water supply is also added from High Level Diversion $(H L D)$ Babak Renggung (BRG). In addition, Renggung watershed also gets water supply from Gule Liat (Fig. 6). About 48.7\% from 53.4 million $\mathrm{m}^{3}$ water of Renggung river comes from the upstream and middle stream catchment area along the river until Ponggong (observation point), 39.4\% from HLD-Babak Renggung, and 11.8\% from Gile Liat (Fig. 6) (Pusat Penelitian Sumber Daya Air dan Agroklimat 2014). Water in downstream of Renggung watershed is overused. It can be said that the level of water usage in Renggung watershed is very high and this makes dependence on water sources from other watersheds such as HLD Babak-Renggung.

The amounts of water in the upstream catchment $(\mathrm{Ny}$ eredet) are 34.8 million $\mathrm{m}^{3}(11.3 \%)$; in the middle catchment area they are 48.6 million $\mathrm{m}^{3}(15.8 \%)$, in Katon they

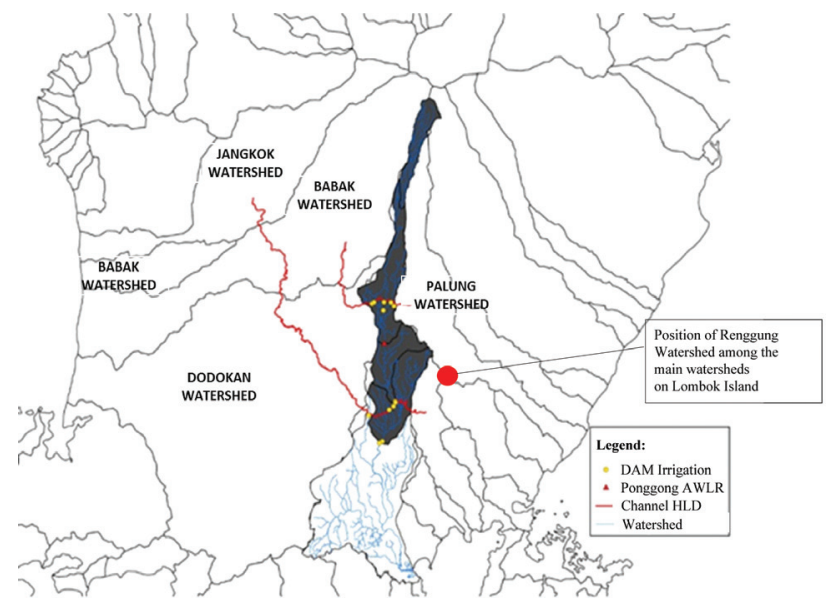

Fig. 6. Position of Renggung Watershed among main watersheds on Lombok Island (Research Center of Water Resources and Agroclimate 2014)

are 24.5 million $\mathrm{m}^{3}(8 \%)$, in Mujur they are 39.4 million $\mathrm{m}^{3}(12.7 \%)$ and in the downstream cathment Mujur are 160.8 million $\mathrm{m}^{3}$ (52.2\%) (Fig. 7). Based on zone (upstream, midstream and downstream), about $72.9 \%$ of potential water is from rainfall in the downstream zone, $15.8 \%$ occurs in the middle zone, and $11.3 \%$ in the upstream zone (Table 2).

Based on the Water Use Index (IPA), only three from five catchment areas along Renggung watershed were in good condition: Nyeredet $(I P A=0.49)$, Katon $(0.3)$, and Mujur (0.54). Two others catchment areas were in poor condition: Ponggong $(I P A=1.46)$ and Hilir Mujur $(I P A=$ 1.12). This means that the amount of water in two catchment areas is overused. IPA $<1$ shows that the amount of water available from rainfall is not fully used. In the upstream area $(I P A<0.5)$, the water use is less than half of water available. This is caused by low population density and unintensive agricultural activity. Catchment areas with $I P A>1$ indicate that water demand in the area exceeds the amount of water provided through rainfall. This is caused by intensive agricultural activity in the region, especially

Table 2. Water availability and needs in each catchment of Renggung watershed; source: Research Center of Water Resources and Agroclimate (2014)

\begin{tabular}{|c|l|c|c|c|c|c|}
\hline No & Cathment Segment & $\begin{array}{c}\text { Area } \\
{[\mathrm{ha}]}\end{array}$ & $\begin{array}{c}\text { Water needs } \\
{\left[\text { million } \mathrm{m}^{3} / \text { year }\right.}\end{array}$ & $\begin{array}{c}\text { Water availability } \\
{\left[\text { million } \mathrm{m}^{3} / \text { year }\right]}\end{array}$ & $\begin{array}{c}\text { IPA/ water use Index } \\
{[\text { per basin] }}\end{array}$ & Category \\
\hline 1 & Nyeredet & 1367.8 & 17.1 & 34.8 & 0.49 & GOOD \\
\hline 2 & AWLR Ponggong & 3075.3 & 86.2 & 48.6 & 1.46 & POOR \\
\hline 3 & Bendung Katon & 1700.8 & 23.0 & 24.5 & 0.30 & GOOD \\
\hline 4 & Mujur & 2986.2 & 41.1 & 39.4 & 0.54 & GOOD \\
\hline 5 & Hilir Mujur & 12469.9 & 192.6 & 160.8 & 1.12 & POOR \\
\hline & Total & 21600.0 & 360.0 & 308.1 & 0.88 & AVERAGE \\
\hline
\end{tabular}

Information : Availability of water is calculated from rainfall on watershed segments added with the river discharge from the watershed segment above it, water requirements are calculated using estimated water use in a variety of land use (Perdirjen RHL and Perhutanan No.: P.4/V-Set/2009, Date: March 05 2009 ) 


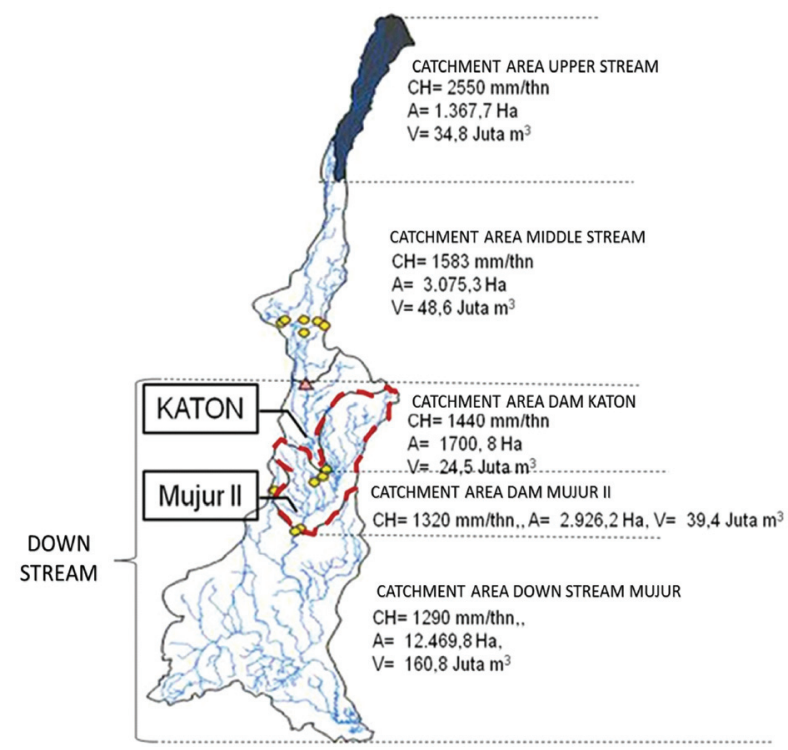

Fig. 7. Distribution of Renggung watershed water potential based on rainfall and basin catchment area: Nyeredet, Ponggong, Katon and Mujur II (Research Center of Water Resources and Agroclimate 2014)

in areas that apply a rice-rice-palawija cropping pattern. This condition may be exacerbated by the tendency of a rice cropping pattern throughout the year (Idris et al. 2014).

\subsection{Rainfed land water management in downstream Renggung watershed}

Rainfed land water management in downstream Renggung Watershed is basically intended for the realization of optimal conditions from vegetation resources, soil, and water so it can give maximum and sustainable benefits. Rainfed land water management in the downstream of the watershed is continually decreasing. This is understood as a process of formulation and implementation of natural and human resources manipulation activities or programmes in Renggung watershed. It is of benefit to production and services without causing damage to soil and water resources; it includes identification of linkages between land use, soil and water, and linkages between upstream and downstream areas of a watershed (Arsyad 2000; Asdak 2002). There are several factors that cause inoptimal water management in rainfed land of downstream Renggung watershed.

\subsubsection{Irrigation water management in the downstream of Renggung watershed}

Water resources in downstream of Renggung Watershed are used to irrigate rainfed land and it depends on the water supply from HLD-BR. Data were obtained from water supply from HLD-BR for the last 6 months (Fig. 8 and 9).

Figures 8 and 9 explain that water supply data of HLD BR to Mujur I and Mujur II watershed had a deficit in meeting irrigation needs in the second and third crop seasons (MT-2 and MT-3). Poor management of water facilities causes watershed can not collect water in large quatities. This causes a lack of water supply for irrigation in the second and third crop seasons (dry season). This will cause a decrease of plant production and crop failure (Research Center of Water Resources and Agroclimate 2014).

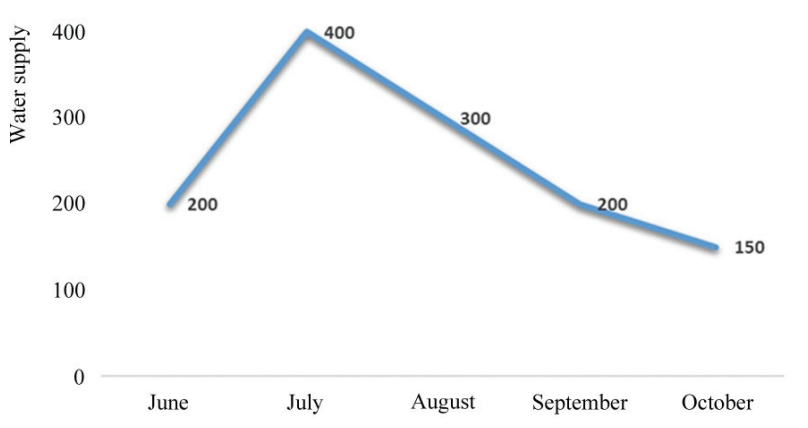

Fig. 8. Discharge of barrier obstructing flowing water Mujur I $[\mathrm{L} / \mathrm{sec}]$ in the last 6 months

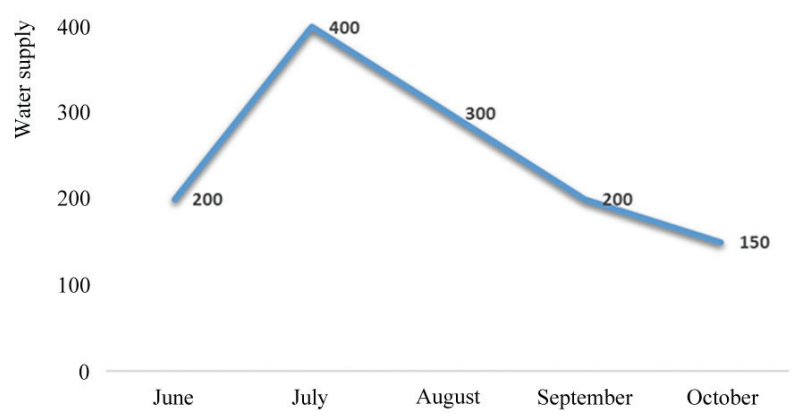

Fig. 9. Discharge of barrier obstructing flowing water Mujur II $[\mathrm{L} / \mathrm{sec}]$ in the last 6 months

\subsubsection{Water management at farming level}

The officer staff of Mujur I and Mujur II watershed stated that not all of the rainfed land in downstream of Renggung watershed was recommended for paddy planting - on MT-2, even more on MT-3, About $40 \%$ and $>20 \%$ of water is used to irrigate in the second (MT-2) and third (MT-3) crop season. Total area of standard irrigation reaches $665 \mathrm{Ha}$ for Mujur I and $3.508 \mathrm{Ha}$ for Mujur II watershed. This is caused by a deficit water supply from the HLD Babak Renggung.

Figure 10 shows the dominance of rainfed land and moors in several subdistricts in downstream of Renggung watershed. The selection of plants should be conducted on a regional basis to get much benefit and to be suitable for 


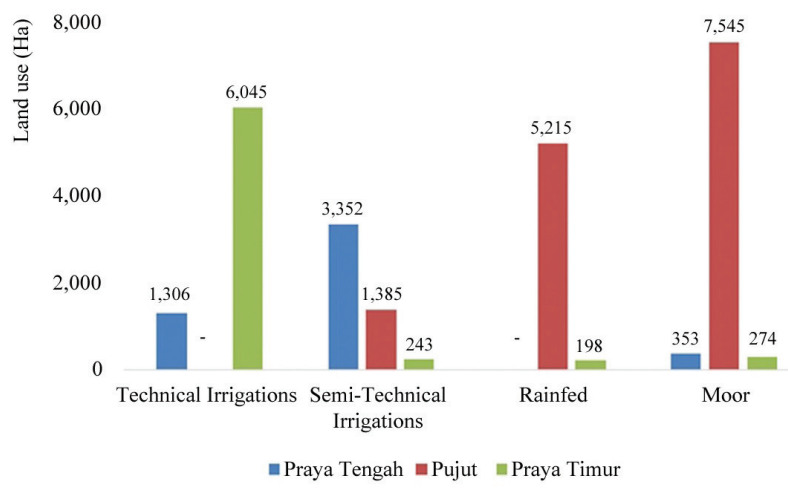

Fig. 10. Land use in downstream Renggung Watershed (Ha)

water resource availability. Based on observation, plant selection was conducted randomly by farmers and they did not heed appeals of watershed officials from the Department of Public Works. Most farmers planted paddy fields not in the right season, which was wasteful and caused a lack of water resources in the middle of cropping season. Development of a linear programme model is very useful for allocating plants in the observation location and it will avoid waste and lack of water resources.

\subsubsection{Institutional of management and water user group}

The success of management at downstream of Renggung watershed is not inseparable from role of community groups in watershed preservation. There were several groups of water users and farmers in downstream of Renggung watershed, but their presence was ineffective. It had no optimal role as a forum for facilitating and mediating some problems in the community (Cybex 2014).

Many conflicts occurred in the community at downstream of Renggung watershed that were caused by a lack of proper management and water utilization, especially a deficit of water irrigation at MT2. This proved that management and the effectiveness of water user groups was still poor.

Some techniques are needed to be applied by managers and groups of water users at rainfed land (vertisol), such as:

a. Raised Beds System.

Plant techniques using Raised Beds System has more advantages in water use efficiency than the system of gora and paddyfield, especially at MT2 and MT3. Surplus water can be accommodated at ponds to be used when experiencing a water deficit. (Ma'shum et al. 2002; Cooten 2010).

b. Manufacture of ponds.

The practice of water management in rainfed land in downstream of Renggung watershed needs to be conducted in surplus months (rainfall $>$ evaporation) by utilizing pond resources. Water reservoirs are used at critical periods during rainy and dry seasons (Rejekiningrum 2002).

c. Determination of proper cropping time.

Timing of cropping and water management in rainfed land entirely depends on the dynamics of rainfall. Rainy season is from November to April, so the determination of appropriate cropping time is better if following the pattern of rain (Yasin et al. 2002; Hamzah 2015).

d. Land management for effectiveness of water usage. Mulsa; some studies show that the use of mulch/mulsa from crop residues, cover crops, and hedge plants can suppress evaporation, especially on rainfed land which has a relatively short number of wet months. In addition, the application of mulch/mulsa can improve the soil's physical properties, such as volume weight, aeration pore, and aggregate stability.

\section{Conclusion}

- Downstream of Renggung watershed is mostly included in Central Lombok Regency, which is $64.8 \%$ of the total area in downstream of Renggung Watershed, whereas $4.3 \%$ is included in East Lombok Regency. It is a rainfed agricultural centre, moorland and also a water conservation area.

- Downstream rainfed land is dominated by vertisol soil which contains the montmorillonite mineral. It causes the soil to shrink in wet conditions and hard soil in dry conditions. Rainfed land is categorized as D3-D4 climate type with 4-6 dry months and 3-4 wet months, with rainfall is about $1200 \mathrm{~mm} /$ year.

- Water supply in the downstream of Renggung watershed comes from three sources, ie from the upstream catchment draining to the downstream $-48,7 \%$, from HLD Babak Renggung - 39,4\%, and Embung/ Ponds of Gule Liat - $11,8 \%$. In the downstream of Renggung watershed the water has been fully used, even exceeding the capability to be provided in the catchment area, because most farmers apply the cropping pattern paddy-paddy-palawija.

- Water irrigarion discharge is decreasing continuously in downstream of Mujur I and Mujur II watershed.

- Water management at the farming level in downstream does not fully reflect the suitability of cropping patterns and amount of water availability.

- The role of management and water-user groups in water management is not optimal, so applying some techniques such as: (a) Raised beds system; (b) Manufacture of embung/ponds; (c) Determination of proper cropping time; and (d) Land management for effectiveness of water usage need to be improved. 
Bibliograpy

ACIAR, 2007, Identification of economic problem in water management and vegetable cultivation in East and West Nusa Tenggara, Australian Centre for International Agricultural Research, ACIAR, GPO Box 1571, Canberra, ACT 2601, Australia

Agus F., 2000, Smallholder acid upland soil management in Indonesia, Soil and Environment, 3 (1), 1-12

Alfian F., 2012, Study of system development of Agroforestry Ecosystem services (BES) in Renggung, Reserch Report

Arsyad S., 2000, Soil and water conservation, Bogor Institute of Agriculture, IPB Press, Bogor, Indonesia

Asdak C., 2002, Hydrology and Watershed Management, Gajah Mada University Press, Indonesia

BISDA, 2012, Rainfall rate in West Nusa Tenggara, Department of Hydrology and Water Resources, Department of Public Work in NTB

BPS, 2014, Land use in West Nusa Tenggara Province, Department of Central Statistic in NTB

Cooten Donald E.V., 2010, Cultivation, Community Development Workers Association, available at: http://cdwi.net/

CYBEX, 2014, The role of Farmer in water resources management, CYBEX - Cyber Extension, available at: http://cybex. pertanian.go.id/

Fauna Flora International (FFI), 2013, Integrated watershed management program in Renggung, Central Lombok, Indonesia

Hamzah M., 2015, Rainfall rate analysis for identifying the cultivation in Aceh, available at: http://etd.unsyiah.ac.id/

Haryati U., Haryono, Abdurachman A., 1995, har management with cultivation system as conservation technology in Typic Eutropepts soil. Ungaran. Central Java, Pembrit. Penel. Tanah dan Pupuk, 13, 40-50

Haryati U., Thamrin M., Suwardjo, 1992, Evaluation of watershed model in Citanduy, Proceeding of soil research, Bogor

Idris M.H., Mahrup, Sukartono, 2014, Water management of Agroforestry development in Renggung Watershed, Water Resources Research Center and University of Mataram Agroclimate partnership with International of Fauna \& Flora
Latham M., 1987, Soil management network - management of Vertisols under semi-arid conditions, [in:] IBSRAM highlights 1986, IBSRAM (International Board on Soil Research and Management), Bangkok, Thailand

Ma'shum M., 2005, (Soil Fertily), Mataram University Press

Ma'shum M., Mahrup, Sukartono, Kusnarta I.G.M., 2002, Vertisols management project in West Nusa Tenggara, Progress report of ACIAR NTB

Markum, Hadi A.P., Suyono, Muktar, 2014, Agroforestry characteristics for watershed management in Renggung, National Seminar of Intergrated Watershed Management for Public Welfare

Nazir M., 2005, Research Method, Ghalia, Indonesia

Oldeman L.R., Las I., Muladi, 1980, The agroclimatic maps of Kalimantan, Maluku, Irian Jaya and Bali, West and East Nusa Tenggara, Central Research Institute for Agriculture, Bogor, Indonesia, $32 \mathrm{pp}$.

Rachman A., Suwardjo H., Watung R.L., Sembiring H., 1989, Erosion management, P3HTA, Badan Litbang Pertanian, Indonesia

Rejekiningrum P., Ummi Haryati, 2002, Rainfall for improving dryland productivity in Nyatnyono, Semarang, Journal of Agrometeorology, 16, 61-75

Research Center of Water Resources and Agroclimate, 2014, (Enviromental Research), available at: http://lemlit.unram. ac.id/pusat-penelitian/pusat-penelitian-sumber-daya-air-danagroklimat/

Sutono, Abdurachman A., 1997, The use of soil conditioner for restoring degrading area, Makalah Review, Cisarua, Bogor, Indonesia

Suwardjo H., 1981, Food waste as soil and water conservation agent, Dissertation, Graduate Program, Institut Pertanian, Bogor, Indonesia

Yasin I., Tarudi M., Soemenaboedhy, Hadiahwaty, 2002, Tools for estimating rainfall rate in Lombok, Reserach Grant Report, Indonesia 